\title{
HUKUM ISLAM DALAM KONTEKS NATION-STATE INDONESIA
}

\author{
Oleh: Muhsin Aseri \\ Dosen DPK pada Sekolah Tinggi Agama Islam Darul Ulum Kandangan
}

\begin{abstract}
Abstrak
Kajian ini dilatarbelakangi Negara Indonesia berdasarkan Pancasila merupakan negara plural. Kemajemukan Indonesia ditandai adanya berbagai agama dianut penduduk, suku, golongan, dan ras. Sebagai potensi, satu sisi agama dapat menjadi pendukung arah pembangunan Indonesia. Pada sisi lain, isu agama dapat pemicu konflik antar umat beragama. Untuk itu kajian posisi dan fungsi hukum Islam hubungannya dengan negara perlu ditelaah. Kajian ini menemukan bahwa di Indonesia Negara dan agama memiliki hubungan sangat erat. Indonesia bukanlah negara agama dan bukan negara sekuler. Indonesia adalah sebuah religious nation state atau negara kebangsaan yang beragama, kebangsaan religius yang menjadikan ajaran agama sebagai dasar moral, sekaligus sumber hukum materil dalam penyelenggaraan kehidupan berbangsa, bernegara dan bermasyarakat.
\end{abstract}

Kata Kunci: Hukum Islam, Nation state, Indonesia.

\section{A. Pendahuluan}

Negara Indonesia merupakan negara yang plural (majemuk) (QS. Al-Hujurat/49; 13 dan UUD 1945 Pasal 29). Kemajemukan Indonesia ini ditandai dengan adanya berbagai agama yang dianut oleh penduduk, suku bangsa, golongan, dan ras. Letak geografis Indonesia yang berada di tengah-tengah dua benua, menjadikan negara ini terdiri dari berbagai ras, suku bangsa, dan agama. Kemajemukan agama di Indonesia tidak terlepas dari perjalanan sejarah bangsa Indonesia itu muncul. Hal tersebut ditandai dengan banyaknya kerajaan di Indonesia yang menganut berbagai macam agama. Tidak diragukan lagi, perjalanan panjang sejarah bangsa Indonesia itu mengakibatkan adanya beberapa agama yang dianut oleh bangsa Indonesia pada masa-masa selanjutnya. Agama bagi bangsa Indonesia merupakan potensi yang besar.

Sebagai potensi, pada satu sisi agama dapat menjadi pendorong dan pendukung arah pembangunan Indonesia. Pada sisi yang lain, isu tentang agama dapat menjadi pemicu konflik antar umat beragama. Oleh sebab itu, hubungan baik antar umat beragama yang terwujud dalam tiga kerukunan hidup beragama Indonesia diharapkan selalu terwujud dalam perjalanan hidup bangsa.

Sejak negara Indonesia merdeka pada tanggal 17 Agustus 1945, hukum Islam memegang peranan yang sangat penting dalam pembentukan hukum di Indonesia selain hukum Belanda yang berlaku saat ini. Gelombang reformasi yang menyapu seluruh kawasan Indonesia sejak kejatuhan Soeharto banyak memunculkan kembali lembaran sejarah masa lalu Indonesia. Salah satu yang hingga kini banyak menjadi sorotan adalah adanya persepsi bahwa Islam adalah nilai yang harus ditegakkan, dengan kata lain tuntutan untuk kembali kepada syariat Islam, atau hukum Islam yang kemudian mengundang beragam kontroversi di Indonesia. Mohammad Natsir mengatakan bahwa negara adalah kekuatan dunia, sedangkan Islam adalah nilai yang harus ditegakkan (Taufiq Nugroho, t.th.; 37). 
Kalau dilihat lembaran sejarah Indonesia, salah satu faktor pemicunya adalah tuntutan untuk mengembalikan tujuh kata bersejarah yang tadinya terdapat dalam pembukaan atau mukaddimah konstitusi Indonesia yang dirumuskan oleh para pendiri negara Indonesia. Tujuh kata itu adalah "dengan kewajiban menjalankan syari' at Islam bagi pemeluk-pemeluknya". Dalam konteks Indonesia, pemikiran hukum Islam sepertinya lebih banyak didominasi oleh warna aliran yang anti perubahan. Ketergantungan kepada teks fiqh klasik yang begitu kuat, dan sempitnya peluang untuk menciptakan syarah interpretatif ketimbang syarah normatif, serta minimnya socio-religious response terhadap kasus-kasus hukum yang banyak terjadi menjadi bukti ketidakberdayaan pemikiran hukum Islam. Untuk itu kajian terhadap hukum Islam hubungannya dengan negara perlu selalu untuk ditelaah dan diaplikasikan.

\section{B. Hubungan Agama dan Negara}

Negara dan agama, di negara sekuler sekalipun, tidak dapat dipisahkan begitu saja, karena para pengelola negara adalah manusia biasa yang juga terikat dalam berbagai macam norma yang hidup dalam masyarakat, termasuk norma agama. Misalnya, meskipun negaranegara seperti Amerika Serikat, Inggris, Jerman, Perancis dan Belanda adalah negara yang memaklumkan diri sebagai negara sekuler, tetapi banyak kasus menunjukkan bahwa keterlibatannya dalam urusan keagamaan terus berlangsung sepanjang entitas agama dan negara itu ada. Bukti empiris keterkaitan tersebut, untuk kasus Indonesia dapat dilihat misalnya dalam perjuangan sebagian umat Islam untuk memberlakukan "dasar negara" dan "hukum" Islam. Hal ini sudah berlangsung lama. Pergumulan itu dilakukan secara berkesinambungan, meski hasilnya adalah kompromi (modus vivendi) dalam bentuk negara Pancasila (Mahfud MD, 2006; 11).

Adanya keterkaitan yang amat erat antara kekuasaan negara di satu sisi dan syari'at di sisi lain sebetulnya lebih dikarenakan karakteristik syari'at itu sendiri yang diyakini sebagai seperangkat norma dan nilai yang total dan komprehensif mengenai kehidupan manusia hingga yang paling detail. Pada kaitannya dengan pelaksanaan syari'at Islam oleh negara, totalitas atau the comprehensiveness syari'at, dapat dipilah menjadi lima level penerapan hukum Islam sebagai berikut:

1. Masalah-masalah hukum kekeluargaan, seperti perkawinan, perceraian dan kewarisan.

2. Urusan-urusan ekonomi dan keuangan, seperti perbankan Islam dan zakat.

3. Praktik-praktik (ritual) keagamaan, seperti kewajiban mengenakan jilbab bagi wanita muslimah, ataupun pelarangan halhal yang bertentangan dengan ajaran Islam seperti alkohol dan perjudian.

4. Penerapan hukum Pidana Islam, terutama bertalian dengan jenis-jenis sanksi yang dijatuhkan bagi pelanggar.

5. Penggunaan Islam sebagai dasar negara dan sistem pemerintahan.

Lima level penerapan hukum Islam di atas, disusun secara heirarki mulai dari terendah hingga tertinggi bobotnya. Dengan demikian, tuntutan untuk menerapkan semua level hukum Islam di atas dengan sendirinya langsung berimplikasi pada tuntutan pembentukan Negara Islam. Mungkin cukup masuk akal jika dikatakan bahwa semakin tinggi level tuntutan penerapan hukum Islam, maka semakin dekat menuju perwujudan gagasan Negara Islam. Begitu sebaliknya, semakin rendah level tuntutan maka semakin rendah pula tingkat komitmen untuk mewujudkan Negara Islam (Arskal Salim, 24/03/2002). 
Al-Qur'an dan Sunnah telah disepakati untuk dijadikan pedoman dalam mengatur tata kehidupan manusia, namun para ulama dan pemikir Islam berselisih pendapat, mengenai sejauh mana aturan-aturan hukum yang terkandung dalam kedua sumber tersebut dapat diaplikasikan (Agus Moh Najib, 2003; 21). Dari berbagai proses pergumulan politik hukum di Indonesia, yang menjadi isu sentral adalah seputar hubungan antar agama dan negara. Bagi kalangan yang menganggap bahwa syari'at Islam meliputi semua aspek kehidupan, adalah tidak mungkin melaksanakannya tanpa bantuan instrumen negara untuk memaksanya. Oleh karena itu, gagasan ini erat kaitannya dengan ide mendirikan Negara Islam (Marzuki Wahid dan Nurrohman, 2001; 22).

Perkembangan peradaban manusia, agama senantiasa memiliki relasidengan negara. Hubungan ini selalu mengalami pasang-surut seiring dengan perkembangan pemahaman dan pemaknaan terhadap agama dan negara itu sendiri. Adakalanya negara sangat dekat dengan agama, atau bahkan menjadi negara agama. Namun di saat lain, agama dan negara mengalami ketegangan relasi.

Hubungan antara agama dan negara dapat dibedakan dalam tiga pola; integral symmetries, integral asymmetries, dan sipil (civil).

Pola pertama, menempatkan agama dan negara menjadi satu dan tidak bisa dibedakan. Ini lebih dikenal dengan theocracy, lebih tepat hierocracy, karena pembesar agama- bukan Tuhan yang langsung memerintah. Seperti di Vatikan dan Iran di bawah pimpinan Khomeini. Pola kedua, bisa berarti "negara dalam agama" maksudnya, sebesar-besarnya kekuasaan negara masih tetap tunduk pada kekuasaan agama, seperti di Taliban. Atau bisa juga "agama dalam negara" berarti, sebesar-besarnya pengaruh agama, kekuasaan itu masih tetap tunduk pada negara. Pola ini menetapkan adanya pluralisme agama negara yang resmi, tetapi dalam prakteknya, tetap saja ada satu agama atau lebih yang dominan, seperti di Indonesia (Parakitri T. Simbolon, 2000; 29). Pola dan contoh hubungan tersebut, selalu menimbulkan perdebatan pemahaman dan tafsiran atas paradigma masing-masing di kalangan pemikir Islam dan negarawan. Implikasi dari perbedaan paradigma dan pemikiran mengenai hubungan antara agama dan negara menimbulkan kecenderungan pemikiran dan sikap mengenai implementasi syari'at (Hukum Islam) dalam suatu negara. Pro-kontra seputar perdebatan tersebut dalam ketatanegaraan Indonesia tidak dapat dilepaskan dari akar wacana tentang hubungan agama (Islam) dan negara yang selalu hadir dan tidak pernah menuai kesepakatan di kalangan pemikir maupun aktivis Islam itu sendiri, baik masa klasik maupun kontemporer (Ahmad Tholabi Karlie; 100).

Hubungan Islam dan ketatanegaraan, menurut Munawir Sjadzali (Munawir Sjadzali, 1993; 1-2; Otji Salman \&Anthon F. Susanto, 2004; 78; A. Fedyani Saifuddin, 2000; 5-6) ada tiga aliran yang dapat dikategorikan:

Pertama, aliran konservatif tradisionalis, berpendapat bahwa Islam adalah agama yang sempurna dalam mengatur aspek kehidupan, termasuk bidang hukum. Dengan demikian, menurut kelompok ini, umat Islam wajib menerapkan aturan-aturan hukum Islam dalam kehidupannya, termasuk kehidupan bernegara. Oleh sebab itu, tidak ada alasan memisahkan keduanya.

Kedua, aliran integratif modernis, yang berpendapat bahwa Islam tidak mempunyai sistem negara yang detail, tetapi di dalamnya terdapat nilai etika kehidupan dan prinsipprinsip umum yang dapat diinterpretasikan dan bisa disesuaikan dengan konteks kehidupan 
bernegara. Model ini akan memperkuat kekuasaan dan menjadikan sistem yang ada melemah karena akumulasi kekuasaan ada di tangan negara, seperti zaman Orde Baru.

Ketiga, aliran nasionalis sekuler, menurut kelompok ini agama (Islam) merupakan agama yang hanya mengatur urusan individu dengan Tuhannya, tidak mengatur hubungan sosial secara konkret, termasuk menetapkan aturan-aturan hukum dalam sebuah negara. Aliran ini agama dan negara berpisah satu sama lain. Doktrin agama hanya menjadi pedoman sebatas dalam keluarga dan masyarakat, yang berwadahkan organisasi dalam Mesjid, Gereja dan sebagainya. Segala sesuatu berkaitan agama diselesaikan institusi tersebut.

\section{Landasan Konstitusional}

Mahfud MD menyatakan, secara yuridis-konstitusional negara Indonesia bukan negara agama dan bukan negara sekuler. Indonesia adalah sebuah religious nation state atau negara kebangsaan yang beragama. Indonesia adalah negara kebangsaan yang religius yang menjadikan ajaran agama sebagai dasar moral, sekaligus sebagai sumber hukum materil dalam penyelenggaraan kehidupan bernegara dan bermasyarakat (Mahfud MD, 2006; 8), karena telah jelas dinyatakan, bahwa salah satu dasar negara Indonesia adalah Ketuhanan Yang Maha Esa. Oleh karena itu dikatakan bahwa Indonesia bukan negara agama, karena tidak berdasarkan agama tertentu, dan juga bukan negara sekuler sebab tidak memisahkan secara tegas antara urusan negara dan urusan agama.

Prinsip Ketuhanan Yang Maha Esa, pertama-tama dirumuskan sebagai salah satu dasar kenegaraan dalam Pembukaan UUD 1945 berdasarkan Ketuhanan Yang Maha Esa. Selain itu, Indonesia juga menganut paham kedaulatan rakyat dan kedaulatan hukum dalam satu kesatuan sistem konstitusional modern. Paham ini mengharuskan kita untuk mengakui adanya ke-Maha Kuasa-an Tuhan Yang Maha Esa. Artinya, Tuhan-lah yang sebenarnya berdaulat atas perikehidupan manusia seluruhnya. Namun kedaulatan Tuhan tersebut tidak mewujud ke dalam kedaulatan Raja, melainkan mewujud dalam konsep kedaulatan rakyat dan kedaulatan hukum (Jimly Asshiddiqie, 2005; h.85-102).

Berdasarkan "prinsip tauhid", keyakinan terhadap Tuhan Yang Maha Esa, maka setiap manusia Indonesia seharusnya hanya memutlakkan Tuhan Yang Maha Esa. Sebagai konsekuensinya, perikehidupan bangsa sudah seharusnya bersifat egaliter, di mana setiap orang dianggap sama hak dan kedudukannya di hadapan Tuhan, apalagi hak dan kedudukannya dalam hukum dan pemerintahan. Prinsip egalitarianisme ini hanya dapat berjalan jika dalam pembuatan keputusan dilakukan atas dasar musyawarah, serta terwujud dalam prosedur pemilihan atau bay'at terhadap wakil rakyat sebagai ulil-amri. Setelah ditetapkan melalui prosedur musyawarah, maka semua keputusan itu mengikat sebagai hukum yang harus ditempatkan menurut prinsip supremasi hukum. Inilah bentuk pelaksanaan dari Kedaulatan Tuhan yang diwujudkan dalam prinsip Kedaulatan Rakyat dan Kedaulatan Hukum (Komaruddin Hidayat, 1994; 189-200).

Dalam konteks Indonesia, karena salah satu nilai dasar negaranya adalah Ketuhanan Yang Maha Esa, maka hukum negara harus mencerminkan esensi keadilan berdasarkan Ketuhanan Yang Maha Esa, yang diwujudkan melalui prinsip hierarki norma dan elaborasi norma. Sumber norma yang mencerminkan keadilan berdasarkan Ketuhanan Yang Maha Esa itu dapat datang dari mana saja, termasuk misalnya dari sistem syari'at Islam ataupun nilai-nilai yang berasal dari tradisi Kristen, Hindu, Budha, dan Konghucu. Pada saat 
nilai-nilai yang terkandung di dalamnya telah diadopsi, maka sumber norma syari'at itu tidak perlu disebut lagi, karena namanya sudah menjadi hukum negara yang berlaku untuk umum.

\section{Kedudukan Hukum Islam dalam Tata Hukum Indonesia}

Maksud kedudukan dalam Tata Hukum Indonesia adalah tempat dan keadaan hukum Islam dalam susunan atau sistem hukum yang berlaku di Indonesia (Mohammad Daud Ali, 1996; 208). Sebagai akibat dari perkembangan sejarahnya, sistem hukum di Indonesia bersifat majemuk. Disebut demikian karena sampai sekarang di Indonesia berlaku beberapa sistem hukum sekaligus, yang mempunyai corak dan susunan sendiri, yakni sistem hukum Adat, sistem hukum Islam dan sistem hukum Barat. Ketiga sistem hukum itu mulai berlaku di Indonesia pada waktu yang berlainan. Ketiganya diakui oleh peraturan perundang-undangan, tumbuh dalam masyarakat, dikembangkan oleh ilmu pengetahuan dan praktek peradilan.

Tiga macam sistem hukum yang merupakan konsekuensi untuk dianut oleh penduduk Indonesia, dapat dilihat sebagai berikut:

1. Dari segi kemajemukan jenis penduduknya, ketika Indonesia masih dijajah Belanda, kebiasaan atau adat istiadat itu disebut dengan "hukum Adat" atau disebut hukum kebiasaan (Customary Law).

2. Dari segi agama, Islam sebagai mayoritas agama penduduk Indonesia, maka hukum Islam (Islamic Law) merupakan salah satu sistem hukum yang berlaku di tengahtengah masyarakat Indonesia.

3. Sebagai negara yang pernah dijajah Belanda selama 350 tahun, jelaslah negara penjajah memaksakan sistem hukumnya di Indonesia, ini kemudian disebut hukum
Belanda atau hukum Barat (Common Law)

(A. Qodri Azizy, 2002; 109-110).

Dengan demikian, dapat dikatakan bahwa di Indonesia berlaku tiga sistem hukum: hukum Adat, hukum Islam, dan hukum Barat, dengan segala perangkat dan persyaratan, siapa saja dan dalam aspek atau esensi apa saja harus mematuhi hukum dari ketiga sistem hukum tersebut. Jadi secara garis besar, sistem hukum di Indonesia meliputi tiga macam, yakni Sistem Hukum Adat, Sistem Hukum Islam dan Sistem Hukum Barat. Dalam perkembangan sistem hukum Indonesia dikemudian hari, ketiga sistem hukum dalam pengertian yang dinamis itu, menjadi bahan baku hukum Nasional (A. Qodri Azizy, 2002; 111).

Hukum Islam, sebagai salah satu bahan baku hukum nasional, semakin Jelas dan konstitusional dengan lahirnya Garis-Garis Besar Haluan Negara (GBHN) tahun 1999, yang merupakan produk konstitusional dalam era Reformasi (A. Qodri Azizy, 2002; 113). Namun sayangnya, sampai kini upaya mewujudkan hukum nasional yang mengIndonesia hasilnya masih sangat sedikit dan baru sebatas retorika politik. Dalam waktu bersamaan, masih pula nampak tanda-tanda belum jelasnya penggarapan terjadinya kompetisi dan akulturasi dari tiga sistem hukum yang merupakan bahan baku hukum nasional di tersebut.

Dari uraian tersebut di atas, dapat disimpulkan bahwa kini di Indonesia; a) hukum Islam yang disebut dan ditentukan oleh peraturan perundang-undangan dapat berlaku langsung tanpa harus melalui hukum Adat; b) Republik Indonesia dapat mengatur sesuatu masalah dengan ketentuan hukum Islam, sepanjang peraturan itu hanya berlaku bagi pemeluk agama Islam; c) kedudukan hukum Islam, dalam tata hukum Indonesia adalah sama sederajat dengan hukum Adat dan hukum Barat; d) hukum Islam menjadi sumber 
pembentukan hukum nasional sekarang dan yang akan datang di samping hukum Adat, hukum Barat dan hukum lainnya yang tumbuh dan berkembang dalam negara Republik Indonesia (Muhammad Daud Ali, 1977, 240).

\section{E. Hukum Islam dan Pembinaan Hukum Nasional}

Membangun dan membina hukum nasional diperlukan politik hukum tertentu. Politik hukum nasional Indonesia, pokokpokoknya ditetapkan dalam Rencana Pembangunan Jangka Panjang Nasional Tahun 2005 - 2025 (RPJPN) yang dulu ditetapkan dalam bentuk Garis-garis Besar Haluan Negara (GBHN) dan dirinci lebih lanjut oleh Menteri Hukum dan HAM Republik Indonesia (dulu Menteri Kehakiman RI) dan Mahkamah Agung Republik Indonesia. Untuk melaksanakannya telah didirikan sebuah lembaga yang bernama Badan Pembinaan Hukum Nasional (BPHN/Babinkumnas). Melalui koordinasi yang dilakukan oleh badan ini, diharapkan di kemudian hari akan terwujud suatu hukum nasional bagi bangsa Indonesia (Muhammad Daud Ali, 1977, 241). Politik hukum itu antara lain berupa mengadakan pembaharuan, kodifikasi serta unifikasi hukum di bidang-bidang tertentu, dengan memperhatikan kesadaran hukum yang berlaku dalam masyarakat (Cik Hasan Bisri, 1998; 80).

Bukanlah pekerjaan yang mudah, memang. Pembangunan hukum nasional yang akan berlaku bagi semua warga negara tanpa memandang agama yang dipeluknya, haruslah dilakukan dengan hati-hati, karena agama yang dipeluk oleh bangsa Indonesia bersifat majemuk. Selain itu, ada agama yang tidak dapat dipisahkan dari hukum, seperti Agama Islam. Oleh karenanya, dalam membangun hukum nasional dalam negara yang mayoritas penduduknya beragama Islam, unsur agama Islam harus benar-benar diperhatikan.
Secara empiris, tidaklah berlebihan jika dikatakan bahwa hukum Islam di Indonesia adalah "hukum yang hidup" (the living law), kendati secara resmi, dalam aspek-aspek pengaturan tertentu, ia tidak atau belum dijadikan kaidah hukum positif oleh negara (Said Agil Munawwar, 2004; 29). Adapun dengan banyaknya pertanyaan dan permasalahan mengenai "hukum" dalam masyarakat yang diajukan kepada para ulama, media massa, dan organisasi-organisasi sosial keagamaan Islam, haruslah dilihat sebagai salah satu isyarat, bahwa hukum Islam adalah hukum yang hidup dalam masyarakat.

Untuk mewujudkan anggapan tersebut, maka dibutuhkan aktualisasi hukum Islam itu sendiri, agar tetap urgen menjadi bagian dari proses pembangunan hukum nasional. Aktualisasi hukum Islam dapat dibedakan menjadi dua bentuk, yakni: pertama, upaya pemberlakuan hukum Islam dengan pembentukan peraturan hukum tertentu yang berlaku khusus bagi umat Islam; kedua, upaya menjadikan syari'at Islam dan fiqh sebagai sumber hukum bagi penyusunan hukum nasional (Yudian Wahyudi, 2006; 36-38). Boleh dikatakan, aktualisasi semacam ini merupakan upaya memberikan jembatan penghubung antara kalangan yang mengusung tema "kembali kepada al-Qur'an dan Sunnah" dengan orientasi ke-Indonesia-an yang konstitusional.

Wujud aktualisasi hukum Islam dalam bentuk peraturan khusus berlaku bagi umat Islam adalah Undang-Undang Nomor 50 Tahun 2009 tentang Perubahan Kedua atas Undang-Undang Nomor 7 Tahun 1989 tentang Peradilan Agama dan keberadaan Kompilasi Hukum Islam (KHI) yang penyebarluasannya dilakukan berdasarkan Inpres Nomor 1 Tahun 1991. Sedangkan aktualisasi hukum Islam dalam hukum nasional yang berlaku umum, misalnya, Undang-Undang Nomor 5 Tahun 1960 tentang Pokok-Pokok Agraria, khususnya yang mengatur tentang Perwakafan Tanah, 
Undang-Undang Nomor1 Tahun 1974 tentang Perkawinan, Undang-Undang Nomor 4 Tahun 1979 tentang Kesejahteraan Anak, dan Undang-Undang Nomor 23 Tahun 2002 tentang Perlindungan Anak.

Masih banyak lagi produk hukum lain yang jika kita teliti, akan menunjukkan aktualisasi hukum Islam sesuai dengan tingkat kesadaran hukum masyarakat Indonesia dan para pembuat peraturan perundang-undangan. Apalagi dengan adanya kebijakan otonomi daerah saat ini, tentu daerah-daerah dapat membuat peraturan daerah sebagai aktualisasi hukum yang hidup dalam masyarakat, khususnya hukum Islam (Ahmad Azhar Basyir, 1999; 7-13). Sekarang tinggal bagaimana dapat memposisikan hukum Islam agar tetap relevan, baik untuk yang berlaku khusus bagi umat Islam maupun yang akan diberlakukan secara umum, dengan tidak mengurangi esensi dan substansi hukum Islam itu sendiri.

Agar proses aktualisasi hukum Islam dapat tercapai dengan baik, perlu diaplikasikan dengan langkah yang sistematis dan terlebih dulu menangani beberapa masalah yang harus diselesaikan seperti:

Pertama, harus terdapat kesadaran bahwa aktualisasi hukum Islam tidak dapat dilaksanakan hanya dengan pernyataan politik bahwa syari'at Islam berlaku bagi umat Islam di Indonesia, sebab pernyataan ini adalah pengulangan tanpa makna. Walau tanpa pengakuan negara, syari' at Islam sebagai jalan hidup tetap berlaku bagi umat Islam.

Kedua, diperlukan pembahasan pada tataran filsafat hukum Islam untuk merumuskan prinsip-prinsip hukum sebagai acuan dalam pengembangan sistem hukum nasional secara keseluruhan.

Ketiga, harus dilakukan pembahasan berdasarkan prinsip hierarki makna dan elaborasi syari'at Islam dan kaidah fiqh untuk menentukan masalah-masalah hukum yang harus diatur dan ditegakkan oleh penguasa, dan yang merupakan urusan pribadi umat Islam.

Keempat, terhadap masalah-masalah hukum yang harus diatur dan ditegakkan oleh penguasa, harus dipilah mana yang berlaku khusus bagi umat Islam dan mana yang dapat diberlakukan secara umum sebagai hukum nasional yang tentu saja harus sesuai, atau minimal tidak boleh bertentangan, dengan norma dan kesadaran hukum masyarakat, termasuk norma agama (Kurniawan Zein, t.th.; 175).

Substansi yang berasal dari sistem hukum Islam hendaklah dirumuskan dengan tepat dan disumbangkan secara produktif untuk kemanusiaan dan ke-Indonesia-an, terutama dalam upaya mewujudkan cita-cita negara hukum Indonesia yang berdasarkan UUD 1945 dan Pancasila. Sekali nilai dan substansi yang disumbangkan telah menjadi norma hukum yang diberlakukan secara konkret dalam sistem hukum negara, maka norma-norma dimaksud berlaku umum bagi semua orang. Karena itu, penamaan simbolisnya sebagai hukum Islam tidak perlu disebut lagi. Dengan demikian cukuplah semua warga negara yang beragama Islam menyebutnya sebagai hukum nasional yang berdasarkan Pancasila dan UUD 1945.

Timbul pertanyaan, apakah ada problem akademis mengenai aktualisasi dan prosedur integrasi hukum Islam ke dalam hukum nasional? Padmo Wahjono, sebagaimana dikutip oleh A.M. Fatwa, menyatakan bahwa dalam kaitannya dengan pembentukan hukum di masa mendatang, ragam politik hukum yang mendasarinya, serta suatu kerangka teori, maka pemahaman tentang Teori Pertingkatan hukum menjadi relevan. Dalam teori ini dinyatakan bahwa berlakunya suatu hukum harus dapat dikembalikan kepada hukum yang lebih tinggi kedudukannya. Jadi, memang tidak ada problem akademis 
(Kurniawan Zein, t.th.; 174).

Teori Pertingkatan hukum beranggapan bahwa berlakunya suatu hukum harus dapat dikembalikan pada suatu hukum yang lebih tinggi kedudukannya. Dengan demikian kita akan mendapatkan pertingkatan sebagai berikut:

1. Ada cita-cita (rechtisde) yang merupakan norma abstrak.

2. Ada norma antara (tussen-norm, general norm, lawin books) yang dipakai sebagi perantara untuk mencapai cita-cita hukum.

3. Ada norma konkret (concrete norm) yang dinikmati orang sebagai hasil penerapan norma atau penegakannya di pengadilan (Anwar Harjono, 1995; 132).

Apabila teori pertingkatan hukum itu diaktualisasikan dan diterapkan pada permasalahan hukum Islam sebagai sumber hukum nasional, maka gambaran pertingkatan hukumnya adalah: a) Norma abstrak/nilai-nilai Islam, yakni nilai-nilai di dalam al-Quran (universal, abadi, dan tidak boleh diubah manusia); b) Norma Antara/asas-asas dan penuangannya ke dalam hukum nasional, yakni asas-asas serta hasil kreasi manusia, sesuai dengan situasi, kondisi, budaya, kurun waktu, muncul sebagai peraturan negara, pendapat ulama atau pakar/Ilmuwan; c) Norma Konkret, terapannya di dalam hukum positif serta penegakannya, yakni semua hasil penerapan dan pelayanan hukum dari kreasi manusia (bukan Nabi) serta hasil penegakan hukum positif di pengadilan. Peragaan teori peringkatan hukum dalam hukum nasional.

Pembinaan hukum nasional,

hendaknya hukum Islam (agama) dijadikan "ruh" dalam rangka membangun hukum nasional yang kokoh dan berlaku rahmatanlila'lamin. Hubungan khas agama dan negara (politik) diibaratkan seperti ruh dan jasad (AM Fatwa, 2009; 181), agama sebagai ruh dan negara ibarat jasad.

\section{F. Kesimpulan}

Negara dan agama, tidak dapat dipisahkan begitu saja, karena para pengelola negara adalah manusia biasa yang juga terikat dalam berbagai macam norma yang hidup dalam masyarakat, termasuk norma agama. Indonesia bukanlah negara agama dan bukan negara sekuler. Indonesia adalah sebuah religious nation state atau negara kebangsaan yang beragama. Indonesia adalah negara kebangsaan yang religius yang menjadikan ajaran agama sebagai dasar moral, sekaligus sebagai sumber hukum materil dalam penyelenggaraan kehidupan berbangsa, bernegara dan bermasyarakat. 


\section{DAFTAR PUSTAKA}

Amal, Taufik Adnan dan Samsu Rizal Pangabean, Politik Syari'at Islam; dari Indonesia hingga Nigeria, Jakarta: Pustaka Alvabet, cet.I, Desember 2004.

Asshiddiqie, Jimly, Konstitusi \& Konstitusionalisme Indonesia, Jakarta: Konstitusi Press, Edisi Revisi, cet. 22, 2005 .

Azizy, A. Qodri, Eklektisisme hukum nasional: kompetisi antara hukum Islam dan hukum umum, Yogyakarta: Gama Media, 2002.

Basalim, Umar, Pro Kontra Piagam Jakarta di Era Reformasi, Jakarta: Pustaka Indonesia Satu, April 2002.

Bisri, Cik Hasan, Peradilan Agama di Indonesia, Jakarta: Raja Grafindo Persada, cet. 2, 1998.

Budiardjo, Miriam, Dasar-Dasar Ilmu Politik, Jakarta: Gramedia Pustaka Utama, 2001.

Burhanudin[ed.], Syariat Islam Pandangan Muslim Liberal, Jakarta: J1. Latas kerjasama dengan The Asia Foundation, 2003.

Daud Ali, Momammad, Hukum Islam dan Peradilan Agama, Jakarta: PT. Raja Grafindo Persada, cet. I, 1977.

Departemen Agama Republik Indonesia, Hukum Islam; Pengantar Ilmu Hukum dan Tata Hukum Islam di Indonesia, Jakarta: PT. Raja Grafindo Persada, cet. 5, 1996.

Departemen Agama Republik Indonesia, Al-
Qur'an dan Terjemahnya,Surabaya: Tri Karya Surabaya, 2004.

Gunaryo, Achmad, Pergumulan Politik dan Hukum Islam, Yogyakarta: Pustaka Pelajar, cet. I, 2006.

Hadi, Sutrisno, Metodologi Research, Yogyakarta: Andi Offset, 1990.

Harjono, Anwar, Indonesia Kita: Pemikiran Berwawasan Iman-Islam, Jakarta: Gema Insani Press, 1995.

Hidayat, Komaruddin, "Tiga Model Hubungan Agama dan Demokrasi," dalam Elza Peldi Taher (ed.), Demokratisasi Politik, Budaya dan Ekonomi, Jakarta: Yayasan Paramadina, 1994.

Mahfud MD, Moh, Perjuangan dan Politik Hukum Islam di Indonesia" makalah disampaikan pada seminar sehari Politik Hukum Islam di Indonesia, diselenggarakan oleh Jurusan JS Fakultas Syari'ah UIN Yogyakarta, 25 November 2006.

Mahfud MD, Moh, Politik Hukum Islam di Indonesia, Jakarta: Pustaka LP3ES cet. III, 2006.

Marzuki Wahid \& Rumadi, Fiqih Madzhab Negara; Kritik Atas Politik Hukum Islam diIndonesia, Yogyakarta: LKiS, 2001.

Munawar, Said Agil, al- Hukum Islam dan Pluralitas Sosial, Jakarta: Penamadani, Cet. I, 2004.

Muttaqin Dadan [et.al.], (eds.), Peradilan Agama \& Kompilasi Hukum Islam dalam Tata Hukum Indonesia, Yogyakarta: UII Press, 1999. 
Nugroho Taufiq, Islam dan Negara Pancasila, Yogyakarta: PADMA, 2003.

Otji Salman \& Anthon F Susanto, Menyikapi dan Memaknai Syari'at Islam Secara Global dan Nasional, Bandung: PT. Refika Aditama, 2004.

Parakitri T. Simbolon, Pasang Surut Hubungan Agama dan Negara di Indonesia, Kompas, (Jakarta), Jumat, 06 Oktober 2000.

Saifuddin A Fedyani (ed.), Agama dalam Politik Keseragaman: Suatu Refleksi Keagamaan Orde Baru, Jakarta: Departemen Agama RI, 2000.

Sjadzali, Munawir, Islam dan Tata Negara: Ajaran, Sejarah dan Pemikiran, Jakarta: UI Press, Edisi 5, 1993.

Sumitro, Warkum, Perkembangan Hukum Islam di Tengah Dinamika Sosial Politik di Indonesia, Malang: Banyu Media, 2005.

Wahyudi, Yudian, Maqashid Syari'ah dalam Pergumulan Politik; Berfilsafat Hukum Islam dari Harvard ke Sunan Kalijaga, Yogyakarta: Pesantren Nawesea Press, 2007.

Wahyudi, Yudian, Ushul Fikih versus Hermeneutika: Membaca Islam dari Kanada \&Amerika, Yogyakarta: Pesantren Nawesea Press, cet. I, 2006. 